\title{
The role of community in restorative justice conferencing
}

\author{
Diana Johns \\ University of Melbourne
}

\begin{abstract}
A B S T R A C T
In examining the role of the community in restorative justice conferencing, this article seeks to highlight the critical aspect of conferencing which differentiates it as a mode of restorative justice: the involvement of supportive others of both victims and offenders; the engagement of a restorative community. Reflection on the nature of this community, and its role in the conferencing process, reveals both its functional and symbolic significance. Drawing on the findings of a study of conferencing for young offenders in Melbourne, Australia, between 2000 and 2003, a detailed picture of the role of the restorative community is presented, largely from the perspective of those most closely involved: young offenders and their families.
\end{abstract}

KEYWORDS: community, restorative justice, conferencing, young offenders. 


\section{Introduction}

...some other forum, outside the harsh rules of evidence which excise context; some better, broader, freer, less rule-bound gathering of the tribe; a forum in which everything might be said, everybody listened to: where bursts of laughter and shouts of rage might not be outlawed: where if people agreed to take turns everyone might at last, at last be heard.

(Helen Garner, 1995, The First Stone, p. 208)

Garner's description evokes a community engaged in a restorative process. The 'gathering of the tribe'-bringing together the social network of significant and supportive individuals around a young person-entails the sharing of experience, free expression of emotion, and listening in a mutually respectful, non-judgmental setting. This article examines the role of such a community in restorative justice conferencing. It reflects first upon the nature of community, in functional and symbolic terms. Then, drawing on the findings of a study ${ }^{1}$ of a conferencing program for young offenders in metropolitan Melbourne, Australia, during the period 2000 to 2003, it explores the restorative process as experienced by conference participants.

\section{The nature of community}

The discussion reveals the critical role played by individuals affected by a crime, in collectively and cooperatively coming together to resolve the issues arising from that experience. Through this mutual restorative process, voices are heard and emotions expressed; behavioural expectations and social norms are conveyed and reinforced; fears are confronted and allayed; insight and empathy are fostered and exchanged; and participants have the opportunity to actively engage in the doing of justice, the righting of wrongs. It emerges that the agency afforded young offenders - their inclusion in the restorative community - may hold the key to attitudinal shifts and subsequent behavioural changes in these young people, which is the very outcome that conferencing seeks to achieve.

\section{Community as 'a space of regulation'}

Restorative justice conceives of crime as conflict between individuals, causing damage to social relationships. It rests on the assumption that this harm may be repaired, and further, that the community, with the government, shares responsibility for dealing with offending behaviour (Braithwaite 1992, p. 36; Bazemore \& Umbreit 1995, p. 304; McCold 1996, p. 90; Polk 1998, p. 497; Wundersitz 2000, p. 111). ${ }^{2}$ Van Ness et al. (1989) assert the principle thus: in promoting justice, the State is responsible for preserving order, and the community is responsible for establishing peace' (in Dyhrberg 1995, p. 135). As Wilkins (1991, p. 312) observes, 'the problem of crime cannot be simplified to the problem of the 
criminal' (in Bazemore \& Umbreit 1995, p. 301); crime exists in a social context. Yet a definitional vacuum exists as to the precise nature and role of the community in its response to crime. In addressing the meaning of community, Hogg and Brown (1985) make an important observation:

Despite the current ubiquity of the term, 'community' remains vague and ill-defined - its positive connotations seem sufficient to guarantee its wide acceptance as self-evidently unproblematic and progressive (p. 402).

These positive connotations - informality and voluntary participation, for instance-tend to be implicitly contrasted with the formal, coercive and institutional nature of state-based activities. The presumption that a 'community based' approach equates to the relinquishment of state power over people's lives is manifest. Clearly, however, notwithstanding its emphasis on community involvement, the conferencing process remains firmly ensconced within the broader justice system, subject to the authority of the court and ultimately the State (Polk 1994, p. 130). In Victoria, for instance, the responsibility for ensuring a young person's compliance with the outcome plan devised at a conference is assigned to a key individual, such as a family member, nominated by the young person. ${ }^{3}$ If the agreement is breached, the case may be referred back to court for further sanctioning (as for the breach of a court order). As such, the community emerges as 'a space of regulation' (Burchall 1981, in Hogg \& Brown 1985, p. 403). But what does this mean in terms of the aim of a group conference to actively engage the community?

\section{The 'community of concern'}

Conferencing is distinguished by its acknowledgement of the social context of offending and the engagement of the community in the restorative process (Strang 2000, p. 24). Yet while references to this context abound, few are accompanied by definitions or explanations of what it actually entails (Schiff 1998, p. 1). Strang includes in this community 'the people in the lives of the victim and offender who care most about them' (2000, p. 22). Moore identifies the process whereby young offenders may 'be reintegrated into their immediate community of interest and into the broader community of people to whom their actions were unacceptable' (1992, p. 205). Presumably, the former refers to the circle of supporters who participate in the conference, often described as the 'community of care' or 'community of concern' (Serventy 1995, p. 253; Strang 2000, p. 23); while the latter comprises the other participants, including victims and their supporters. But what is it about this group that makes them a community, beyond their coming together to collectively resolve the implications of a crime? And is this a valid basis on which to conceive of a community?

\section{A symbolic 'bringing together'}

A community may be characterised by collectivity and interdependence, whether on the large scale of an urban settlement, or a small-scale social network or professional group (SeymourSmith 1986, p. 46). While the familiar construct of a community connected by shared 
interests or activities (a sporting club, a geographical locale, or a religious congregation, for example) evokes an image of a fixed and identifiable entity, in the context of a conference community comprises the temporary coming together of people, or their representatives, who are linked by their common experience of having been affected by a crime (Belgrave 1996, s. 5.3). Certainly, the involvement of crime victims in the process of holding offenders accountable is engaging members of the broader social community in a way that traditional courtroom processes fail to achieve. Yet the inference that the process creates enduring bonds between victims and offenders (Serventy 1995, p. 254) requires further explanation. ${ }^{4}$ More important is that different forms of community be acknowledged and each recognised as: 'a shifting outcome of diverse social interventions and practices, neither internally cohesive nor fixed in space and time' (Hogg \& Brown 1985, p. 402). The restorative community, then, does not actually exist prior to or after a conference; it is merely symbolic of the nature of social life as collective and interdependent. Community is at once symbolised by the group participating in the process - a microcosm of the social world at large-and actually represented by the individuals present, who each bring to the conference a set of values, beliefs and aspirations that are shared and melded in the restorative process. The conference group, as Moore suggests, 'offers an alternative sphere of justice ... larger than the family but ... [with] shared understandings about "common decency"' (1992, p. 214).

The conference functions as a symbol of mutual and cooperative endeavour, invoked in order to communicate a range of messages: the young person's behaviour has far-reaching and harmful consequences, for which they are responsible; they have an obligation to make amends; and, in doing so, they may realise a capacity for agency ${ }^{5}$ in determining their own outcomes. Furthermore, the consideration and discussion of remedies is a collective process of give and take, reinforcing the notion of participants belonging to a community and playing a part in the construction and reaffirmation of moral meanings (Becker 1973, p. 184). In such an interactionist process, symbols are the means by which pedagogic communication is conveyed, such as the clarification of norms, ${ }^{6}$ and through which symbolic reparation may occur (Retzinger \& Scheff 1996, p. 316). The conference community, as a symbol of collectivity, thus serves to diminish an adolescent's perception of individual isolation, while augmenting a sense of responsibility to others and fostering an awareness of their potential for social agency. For example, South Australian researchers found that young people, rather than being 'powerless youth in a roomful of adults', were able to 'hold their own' in the majority of conferences observed (Daly 2001, p. 23). Through dialogue and group decisionmaking, within 'a context of mutual respect' (Walgrave 2002, p. 106), participants in the restorative process are enabled, empowered and encouraged to resolve the issues bringing them together. Thus while conferencing serves as a mechanism for social control, importantly, it does so in a way that is inclusive.

\section{The emotional context}

A key ingredient in the expression of ideas and expectations about behaviour and responsibility is the emotional context in which they are conveyed. ${ }^{7}$ Ideally, in a conference, this comprises 'compassion and understanding' (Daly \& Hayes 2001, p. 2). ${ }^{8}$ Subsequently, 
through empathic resonance, shifts in the attitudes, awareness and perceptions of participants may occur. This process may be further understood within the framework of Tomkins' (1962) theory of human affects; psychological affect theory, as articulated by Nathanson (1992), is linked to the experience of shame, emotion and empathy in the conference process (Moore 1993, in Serventy 1995, pp. 247-9; Moore \& O'Connell 1994, p. 71; Moore et al. 1995, pp. 17-23; O'Connell et al. 1999, p. 23). Compared to the courtroom procedure which relegates victims and offenders to passive roles (Naffine \& Wundersitz 1994, p. 249), the conference is an active process in which all participants are engaged, 'providing an outlet for expressing feelings and moving beyond shame' (O'Connell et al. 1999, p. 28). By encouraging the free expression of emotion in an environment of sharing and listening, the intensity of feelings may be tempered and subsequently transformed. This process of moving from one negative emotional state to another more positive one, through the development of empathy, Tomkins describes as 'affective resonance' (O'Connell et al. 1999, p. 25).

It is through such an empathy-building process that social standards and behavioural norms may be absorbed and accepted as legitimate by the young offender, through what Katz terms 'empathic responsiveness' (2002, p. 32). Further, it is through the empathic, interactional process that the potentially enduring nature of the relationship (with its accompanying moral obligations) established between participants during the conference process may be recognised. This notion of a continuing relationship is essential to the idea of the expression and maintenance of 'moral cohesion' (Griffiths 1970, p. 387), ensuring people's commitment to society's conventional norms and institutions (Becker 1973, p. 27), that is the basis, surely, upon which 'community' is sustained.

\section{The study and its findings}

The role played by the community in restorative conferencing is illuminated by findings of the study (Johns 2005) on which this paper draws. Seven conferences were observed involving seven young men aged 14 to 18 , whose offences ranged from property-related to assault and armed robbery. 'A' to 'G', assigned alphabetic aliases for the purposes of anonymity and confidentiality, each participated in a conference with victims (or victim representatives), as well as their own significant others for support. Also present were the police informant and the young person's lawyer. Following their conferences, in-depth face-to-face interviews were conducted with three of the young men and their supports; another mother was followed up briefly by telephone. Additional interviews and a focus group with key stakeholders yielded perspectives on the process of professionals - convenors, victim representatives, police and lawyers. The findings derive from observational notes taken during the conferences, as well as transcriptions of interviews and the focus group, which were later analysed abductively.

The discussion below reveals critical aspects of the role of community in the conference: victims are given a voice, and heard; the offending behaviour is located within a social context; the young person is confronted by the harm they have caused and thus held accountable for their actions, within a safe and supportive environment; and they are granted the opportunity 
for engagement in the reparative process. This article opened with Garner's (1995) evocation of a community engaged in such a process. The significance of each member being listened to, being heard, is revealed in the findings that follow.

\section{Being heard}

'A' was with a group who were 'badging' and stealing from cars, including that of his friend's sister. She attended the conference ensuing from his arrest and subsequent court appearance. This young woman's experience illustrates the importance of being heard: it was not the seriousness of the crime that concerned her; she had only a few dollars and some cigarettes stolen. She wanted A, however, to understand her feelings of disappointment and betrayal. A's pledge to recover a badge for her car made both material and symbolic reparation (Retzinger \& Scheff 1996, p. 316), symbolising his accountability for causing the damage and his efforts to repair it. This marked his acceptance of the conference group's norms and expectations as legitimate (Bilton et al. 1996, p. 12), a sign of his moral development, maturity and 'ability to self-reflect', as noted by his youth worker.

Mutual respect emerges as fundamental to the process of listening and being heard through which such reconciliation may occur. This includes the offender having the chance to say, for example, 'I never meant to harm anyone, I never even realised I would, I just wanted the money ...' (cited by conference convenor, focus group). Being heard may be enough for some victims, such as in A's conference. In another case, the family of the victim of a serious assault needed the young person, B, to see and hear how his actions had affected all of them so severely. In F's conference, one victim 'thought some nice gesture [that F thought up himself] would be alright' (Johns 2005, p. 171), while another wanted F to know he was still very angry. Others demand an apology or an explanation, or more substantial recompense. Another victim of A's actions who was absent from his conference, for instance, requested compensation for the $\$ 800$ he was out-of-pocket for the excess on his insurance claim and the cost of repairing his front door; A (being one of four co-offenders) promised $\$ 200$. D's victim wanted D to pay a third of his $\$ 3000$ costs (for the criminal damage to his machinery), while E's victim requested that $\mathrm{E}$ and his co-offenders repay him $\$ 400$ for medical expenses following their violent assault. In some cases victims' intents varied, making restoration more challenging.

For offenders, confronting the harm they have caused evokes fear of unrelenting and possibly vengeful condemnation. The respectful listening conditions established by the convenor are therefore crucial, to 'avoid loose cannons" (F's lawyer, interview), since young people's readiness to engage in the restorative process - to apologise and make amends for their actions - depends upon their feeling safe and supported in it. These factors hinge on the trust and confidence the convenor is able to foster, and the presence of caring others to and by whom the young people feel connected and supported, and from whom they get a 'good response' (A's youth worker). The positive connotations of this community ${ }^{10}$ derive from its inherent care and concern for the young person. Implicit is its willingness to support them in the restorative and reintegrative process, with a sense of 'mutual commitment' (Salomone 2003, p. 7). 


\section{Community as social context}

Community involvement in the conference emerges as critical for victims to see the offender's actions in a social context (Cernkovich \& Giordano 1987, p. 295; Shoham \& Hoffmann 1991, p. 98; Wilkins 1991, p. 312, in Bazemore \& Umbreit 1995, p. 301). As a police officer observed, 'having the family there, having the police there, having the victims there [creates an] environment where more comes out so everyone gets a better understanding of what happened (police officer, focus group). Thus, 'the young person isn't seen as a single entity ... there are family dynamics' (lawyer, focus group). It is often through the young person's supports that empathy-inspiring information is shared, such as the father who divulged that his terminal illness triggered his son's 'crime spree': 'the victim ended up saying, "God if I was in your shoes I probably would have done something worse" (victim representative, focus group). Such disclosure promotes restoration by creating 'an understanding of what this young person was going through' (victim representative, focus group).

Police, too, form an important part of the conference community. Reportedly, young people 'always ask: "Will the police officer be there who arrested me?" ... "Who will be there from the police?" ... "Do they know me?" (lawyer, focus group). Apparently, seeing the officer who arrested them evokes a feeling of familiarity, of connectedness. ${ }^{11} \mathrm{C}$, for instance, felt he could rely on the police officer for support in his conference (Johns 2005). For young people, the interaction with police under atypical circumstances is meaningful:

Whether or not they came in uniform ... they saw the police as not just there to get stats up, to punish them, but to act as a go-between, they really did see [them] in a different light ... as someone who was really interested in the outcome (police officer, focus group).

This highlights the function of the conference as a symbolic community: the participants represent a wider circle of people with an interest in the offender's reintegration, if only for their own safety and reassurance (McCold 1996, pp. 92-3). The young person's perception of this genuine interest fosters the mutual respect required for reintegration to begin (Walgrave 2002, p. 106; Salomone 2003, p. 7).

\section{Confronting community}

Conversely, restorative success may not arise if safety, support and respect are not perceived by the young person. For instance, G's feelings of connectedness to and support from his parents might have been diminished by their empathy with the victims and the group's subsequent sermonising: ' $G$ ] hears us preaching ... [it's good for him to be] hearing everyone else say the same thing' (G's father, conference). This collective moralisation may have been alienating for $\mathrm{G}$, which highlights the danger of the 'moralising impact of shaming' (Braithwaite 1989 in Prichard 2002, p. 332) and the risk inherent in the community as a space of regulation. As Stubbs warns, '[w]e shouldn't presume that the informal is necessarily benign or even neutral' (in Alder \& Baines 1996, p. 46). Family support may be laden with expectations (Prichard 2002, p. 333), which may heighten the young person's experience of shame. In fact, many speak of their remorse in terms of the 'shame that they've brought to 
their family' (victim representative, focus group). Potential stigmatisation reinforces the need for young people to feel safe and supported, to strengthen their prospects of reintegration.

Notwithstanding the support of the young person's community, the confrontation between victim and offender in the contained setting of the conference is 'pretty tough' (E, interview); 'horrible' (D's father, interview); with 'not a lot of upside' for the young person, having 'to sit here and listen' (G's lawyer, conference). As indicated, the victims' presence magnifies this experience, whereby feelings of shame and remorse are apparently intensified for the young people and their supports. A lawyer reported one client being so nervous, 'his first words were, 'just bash me ... that's all I want you to do, let's just get it over with' (lawyer, focus group). According to another, 'it's especially difficult for the young person if they're under attack ... or if they're getting the third degree- "why did you do it?"that sort of pressure' (F's lawyer, interview). G's discomfort was evident, when asked to 'try and verbalise how it feels at this point' (victim, G's conference). ${ }^{12}$ Adults expressed anxiety about addressing the group. ${ }^{13}$ Adolescents could conceivably feel more apprehensive, as A hinted: 'I couldn't look 'em in the eye' (A's interview). Clearly, the confronting experience is a punishing one (Daly 1999, p. 10; Barton 2000, pp. 1, 21). While condemnation of the offending actions is necessary, the confrontation needs to occur within a context of sustained respect and support for the young person (Braithwaite 1989), if the potential stigmatising effects of shaming are to be avoided.

\section{Young people's engagement}

During the conferences observed, changes in the young people's demeanour reflected shifts in the nature of the exchange and the flow of power: eyes fixed on the floor, crossed arms, feet and legs thrust into the circle, for instance, contrasted markedly with eye contact, open hands, and leaning into the circle. This was seen as a relaxing of tension in the room and ebbing of victims' power over the group. The sense of relief at the conclusion of the information stage, for example, was manifest in body language such as: '[E's] leaning forward into the group, hands together, making eye contact. His parents are watching [E] as he speaks' (E's conference, observational notes). Focus group participants made similar observations. These emotional and attitudinal shifts signify the young people engaging with the process. As A's grandmother noted of $\mathrm{A}$, 'he was quiet and controlled and stopped before he said things ... normally, you know, he rants and raves a bit' (in interview). E's parents watching him indicated the supports' role as witness to this engagement. The 'pedagogical possibilities' (Christie 1977, p. 8) of this experience emerge as conditional upon aspects of the conference process: the physical and emotional support of a 'community of care' (including but not necessarily family); conditions of mutual respect and listening; and the ensuing prospect of agency for the young person. Any deficit in these factors appeared to undermine the capacity of the process to engender reparative and reintegrative outcomes (Johns 2005). 


\section{Conclusion}

Community involvement in conferencing is clearly a crucial component of the restorative process. The significance of community is manifest in both symbolic and functional terms. On one hand, the conference community serves to represent and reinforce the framework of social norms and behavioural expectations shared by the law-abiding citizenry. The community is evoked as an emblem of mutual and cooperative endeavour towards this common ideal. By involving crime victims (and/or their representatives) and their supports, police, the young offender, their lawyer and significant others, and the convenor to facilitate the dialogue and reparative discussion, the restorative community aims to represent all the parties affected by the offence. The circle of chairs on which the participants are seated conjures symbolically the ripple effect of the young person's actions, as well as removing the adversarial overtones of traditional justice processes. Of particular symbolic significance is the police presence, representative of state authority yet in a less formal, more open setting.

On a functional level, the conference community comprises the people who are there for the young offender, those individuals to whom and by whom they feel connected and supported. The presence of this 'community of care' or 'community of concern' is distinguished by their ongoing commitment to the welfare and reintegration of the young person. The broader community of interest comprises the individuals directly harmed by the young person's offending and whose interest in the reparative process reflects a range of needs. Common is victims' need to express their emotional responses and feelings such as anger, fear, shock and disappointment; or to simply relate the aftermath of the event to the young person, to make them aware of the consequences of their actions. Many victims need to put the young person and their behaviour into context, to see that they are not as powerful and terrifying as they imagined, for example. Clearly, the need for the offender to make amends for the harm caused is paramount, whether in the form of an apology, symbolic reparation, or financial recompense. Some victims may wish to confront the offender in order to shame them, to invoke genuine remorse. Generally, victims are motivated to participate in a conference to witness the offender taking responsibility for what they have done, and to be assured that they will not do the same thing again.

For the young people themselves, the active role of participating in the restorative community - this group of people gathered to talk, to listen to each other, and to resolve the problem that brought them together-provides a rare opportunity. It is a chance to undo some of the harm that has been done. Confronting the consequences of their actions and taking responsibility is easily avoided in a courtroom situation, for example. Similarly, in a traditional adversarial setting, the prospect of assuming agency in directing their own outcomes appears remote. Engaging in the face-to-face conference process is challenging, confronting, shameful and terrifying for young people. By doing so, however, they may develop awareness and understanding of how their actions impact on others, including - and often most significantly - those closest to them. Thus young people are apt to modify their thinking and behaviour which translates, as research consistently suggests, into the reduction of at least the severity of their reoffending. 


\section{Notes}

1 The research to which this paper refers, Re-engaging families with their young people: A qualitative study of juvenile justice group conferencing in Victoria, was carried out by Diana Johns in fulfilment of the degree of Master of Arts in Applied Criminology, 2005, RMIT University, Victoria, Australia.

2 Braithwaite goes further, arguing: 'the rule of law will amount to a meaningless set of formal sanctioning proceedings which will be perceived as arbitrary unless there is community involvement in moralizing and helping with the crime problem' (1989, p. 8).

3 This reflects Donzelot's (1979) observation of the Children's Court as having effected 'government through the family', whereby the family becomes a site of intervention (in Cunneen \& White 1995, p. 21).

4 For example, the New Zealand Ministry of Justice discussion paper (1996) states: 'Marshall (1992) has suggested that modern realities require an adjustment in thinking about what constitutes a community. He suggests that communities of geography (neighbourhood, parish, suburb, or village) have largely given way to communities of association (friends, clubs, professional and work associations) and membership of these is flexible over time. A combination of members of communities of geography and association may be said to constitute a community of interest in respect of offending incidents' (Belgrave 1996, s. 5.3).

5 'Agency' is defined as 'the capacity (recognised both in a formal, political and legal sense as well as socially) to exert influence and power in a way that is not mediated through adult authority' (Hogg \& Brown 1985, p. 410).

6 See Birenbaum \& Sagarin’s (1976, pp. 1-29, 59) discussion of norms and how they are communicated.

7 For example, reporting on data collected for the SAJJ Research Project (Daly et al. 1998), Daly notes that conferences are marked by calmness and civility; anger, aggressiveness, or arguing was observed in up to ten per cent of conferences, while participants cried in one quarter of meetings (Daly 2001, p. 23).

8 Whether this ideal context of 'compassion and understanding' arises out of thorough pre-conference preparation with participants or automatically out of the experience of the conference process itself, however, is yet to be documented.

9 This might include victim representatives 'going on too long' (F's lawyer, interview).

10 This community is variously described as a 'community of interest' (Moore 1992, p. 205), 'community of care' (Serventy 1995, p. 253), and 'community of concern' (Strang 2000, p. 23).

11 See Resnick et al. 1993; Resnick et al. 1997, for discussion of the significance of 'connectedness'.

12 The researcher's observation of G's body language at this point inferred his shame: '[G] looks down at the floor, head down' (G's conference).

13 A's grandmother and E's mother and father (in interviews), and G's mother (in the conference) spoke of their nervousness and apprehension about participating in the conference. 


\section{References}

Alder, C \& Baines, M 1996, ... and when she was bad: Working with young women in juvenile justice and related areas, National Clearinghouse for Youth Studies, Canberra.

Barton, C 2000, 'Empowerment and retribution in criminal and restorative justice', in H Strang \& J Braithwaite (eds), Restorative justice: Philosophy to practice, Dartmouth/ Ashgate, Aldershot, England.

Bazemore, G \& Umbreit, M S 1995, 'Rethinking the sanctioning function in juvenile court: Retributive or restorative response to youth crime', Crime and Delinquency, vol. 41, pp. 296-316.

Becker, H 1973, Outsiders, The Free Press, New York.

Belgrave, J 1996, Restorative justice: A discussion paper, Ministry of Justice, Wellington, New Zealand, <www.justice.govt.nz/pubs/reports/1996/restorative $>$.

Bilton, T, Bonnett, K, Jones, P, Skinner, D, Stanworth, M \& Webster, A 1996, Introductory sociology, Macmillan, London.

Birenbaum, A \& Sagarin, E 1976, Norms and human behaviour. Holt, Rinehart and Winston, New York.

Braithwaite, J 1989, Crime, shame and reintegration, Cambridge University Press, Cambridge.

Braithwaite, J 1992, 'Juvenile offending: New theory and practice', in L Atkinson \& S-A Gerull (eds), National conference on juvenile justice, Australian Institute of Criminology, Canberra.

Cernkovich, SA \& Giordano, PC 1987, 'Family relationships and delinquency', Criminology, vol. 25, pp. 295-321.

Christie, N 1977, 'Conflicts as property', British Journal of Criminology, vol. 17, pp. 1-15.

Cunneen, C \& White, R 1995, Juvenile justice: An Australian perspective, Oxford University Press, Melbourne.

Daly, K 1999, 'Restorative justice and punishment: The views of young people', paper presented to the American Society of Criminology Annual Meeting, Toronto, 17-21 November 1999, available online: <www.gu.edu.au/school/ccj/kdaly.html>.

— 2001, 'Conferencing in Australia and New Zealand: Variations, research findings, and prospects', in A Morris \& G Maxwell (eds), Restoring justice for juveniles: Conferencing, mediation and circles, Hart Publishing, Oxford; available online: <www.gu.edu.au/ school/ccj/kdaly.html>.

Daly, K \& Hayes, H 2001, Restorative justice \& conferencing in Australia, Trends and issues No. 186, Australian Institute of Criminology, Canberra, pp. 1-6.

Daly, K, Venables, M, McKenna, M, Mumford, L \& Christie-Johnson, J 1998, Project overview and research instruments, South Australia Juvenile Justice (SAJJ) research on conferencing, Technical Report No. 1, School of Criminology and Criminal Justice, Griffith University, Queensland.

Dyhrberg, M 1995, 'Sentencing of Children in New Zealand: A new direction', Criminal Law Journal, vol. 19, pp. 133-8.

Griffiths, J 1970, 'Ideology in criminal procedure or a third 'model' of the criminal process', The Yale Law Journal, vol. 79, pp. 359-417. 
Hogg, R \& Brown, D 1985, 'Reforming juvenile justice: Issues and prospects', in A Borowski \& JM Murray (eds), Juvenile delinquency in Australia, Methuen Australia, Sydney, pp. 393-412.

Johns, D 2005, Re-engaging families with their young people: A qualitative study of juvenile justice group conferencing in Victoria, RMIT University, Melbourne.

Katz, RS 2002, 'Re-examining the integrative social capital theory of crime', Western Criminology Review, vol. 4, pp. 30-54.

McCold, P 1996, 'Restorative justice and the role of community', in B Galaway \& J Hudson (eds), Restorative justice: International perspectives, Criminal Justice Press, Monsey, New York, pp. 85-101.

Moore, DB 1992, 'Facing the consequences', in L Atkinson \& S-A Gerull (eds), National conference on juvenile justice, Australian Institute of Criminology, Canberra.

Moore, DB \& O'Connell, T 1994, 'Family conferencing in Wagga Wagga: A communitarian model of justice', in C Alder \& J Wundersitz (eds), Family conferencing and juvenile justice: The way forward or misplaced optimism? Australian Institute of Criminology, Canberra, pp. 45-86.

Moore, DB, Forsythe, L \& O'Connell, T 1995, 'A new approach to juvenile justice: An evaluation of family conferencing in Wagga Wagga', Charles Sturt University, Centre for Rural Social Research, Riverina, NSW.

Naffine, N \& Wundersitz, J 1994, 'Trends in juvenile justice', in D Chappell \& P Wilson (eds), The Australian criminal justice system: The mid 1990s, Butterworths, Sydney, pp. 235-52.

O'Connell, T, Wachtel, B \& Wachtel, T 1999, Conferencing handbook: The new REAL justice training manual, The Piper's Press, Pipersville, Pennsylvania.

Polk, K 1994, 'Family conferencing: Theoretical and evaluative concerns', in C Alder \& J Wundersitz (eds), Family conferencing and juvenile justice: The way forward or misplaced optimism? Australian Institute of Criminology, Canberra, pp. 123-40.

— 1998, 'The future of juvenile justice', in A Borowski \& I O'Connor (eds), Juvenile crime, justice and corrections, Longman, South Melbourne, pp. 489-501.

Prichard, J 2002, 'Parent-child dynamics in community conferences-some questions for reintegrative shaming, practice and restorative justice', The Australian and New Zealand Journal of Criminology, vol. 35, pp. 330-46.

Resnick, MD, Harris, LJ \& Blum, RW 1993, 'The impact of caring and connectedness on adolescent health and well-being', Journal of Paediatric Child Health, vol. 29, Suppl. 1, S3-S9.

Resnick, MD, Bearman, PS, Blum, RW, Bauman, KE, Harris, KM, Jones, J, Tabor, J, Beuhring, T, Sieving, RE, Shew, M, Ireland, M, Bearinger, LH \& Udry, JR 1997, 'Protecting adolescents from harm: Findings from the national longitudinal study on adolescent health', Journal of the American Medical Association, vol. 278, pp. 823-32.

Retzinger, SM \& Scheff, TJ 1996, 'Strategy for community conferences: Emotions and social bonds', in B Galaway \& J Hudson (eds), Restorative justice: International perspectives, Criminal Justice Press, Monsey, New York, pp. 315-36. 
Salomone, J 2003, Issues Paper 9: Community Engagement, Low Security Prison for Women Project, Department of Justice, Western Australia.

Schiff, MF 1998, 'Restorative justice interventions for juvenile offenders: A research agenda for the next decade', Western Criminology Review, vol. 1, <http://wcr.sonoma.edu/v1n1/ schiff.html>.

Serventy, N 1995, 'Crime, shame and ritual re-integration: A new model of victim/offender reconciliation', Australian Dispute Resolution Journal, vol. 6, pp. 243-56.

Seymour-Smith, C 1986, Macmillan dictionary of anthropology, Macmillan Press, London.

Shoham, SG \& Hoffmann, J 1991, A primer in the sociology of crime, Harrow \& Heston, New York.

Strang, H 2000, 'The future of restorative justice', in D Chappell \& P Wilson (eds), Crime and the criminal justice system in Australia: 2000 and beyond, Butterworths, Sydney, pp. 22-33.

Walgrave, L 2002, 'Not punishing children, but committing them to restore', in I Weijers \& A Duff (eds), Punishing juveniles: Principle and critique, Hart Publishing, Oxford, pp. 93-114.

Wundersitz, J 2000, 'Juvenile justice in Australia: Towards the new millennium', in D Chappell \& P Wilson (eds), Crime and the criminal justice system in Australia: 2000 and beyond, Butterworths, Sydney, pp. 102-18.

\section{About the author}

Diana Johns holds a bachelor's degree in criminal justice administration and a masters degree by research in applied criminology from RMIT University, Melbourne, Australia. Her research interests are in restorative justice, juvenile offending and the experience of vulnerable populations within the criminal justice system. She has experience as a caseworker with unemployed people facing significant non-vocational barriers, such as mental illness, drug and alcohol problems, family breakdown, homelessness and social isolation. She has recently commenced a PhD on post-release support for prisoners as part of The Australian Prisons Research Project, an ARC-funded research project based at the University of New South Wales and the University of Melbourne.

Email: dfj@alphalink.com.au 


\section{University Library}

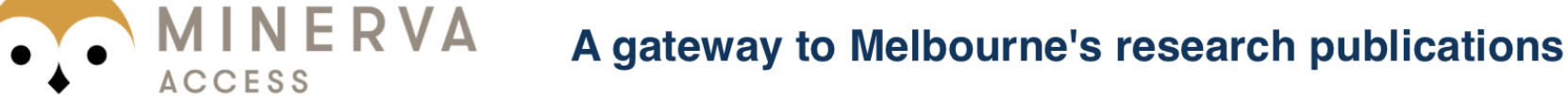

Minerva Access is the Institutional Repository of The University of Melbourne

Author/s:

Johns, D

Title:

The Role of Community in Restorative Justice Conferencing

Date:

2009-02-01

Citation:

Johns, D. (2009). The Role of Community in Restorative Justice Conferencing. Occasional series in criminal justice and international studies, https://doi.org/10.2139/ssrn.2441065.

Persistent Link:

http://hdl.handle.net/11343/252795 